\title{
Applicability of Leaf Morphology and Intersimple Sequence Repeat Markers in Classification of Tree Peony (Paeoniaceae) Cultivars
}

\author{
Zhi-li Suo ${ }^{1}$ \\ Laboratory of Systematic and Evolutionary Botany, Institute of Botany, Chinese \\ Academy of Sciences, Beijing 100093, China
}

Wen-ying Li
Institute of Forestry Policy and Information, Chinese Academy of Forestry,
Beijing 100091, China

Juan Yao, Hui-jin Zhang, and Zhi-ming Zhang

Beijing Botanical Garden, Chinese Academy of Sciences, Beijing 100093, China

\section{Di-xuan Zhao \\ Yutian Tree Peony Nursery, Heze, Shandong Province 274001, China}

Additional index words. Paeonia suffruticosa, cultivar identification, leaf morphology, intersimple sequence repeat marker, ISSR

\begin{abstract}
Tree peony cultivars are usually classified according to flower characteristics (flower form and flower color) which are commonly affected by environmental influences and developmental levels. Judgment of flower forms may also depend on the observer. Precise and rapid cultivar identification methods are also required to manage cultivar collections as well as tree peony breeding programs. The objective of this paper is to analyze the discriminatory ability of leaf morphology and Intersimple sequence repeat (ISSR) marker systems for tree peony cultivars. As a result, although there exist large variations of leaf morphology of tree peony cultivars, the morphological characteristics of biternately compound leaves 3,4 , and 5 from the base of a shoot at the middle part of a plant are relatively stable with smaller variations within cultivars $(2.7 \%$ to $27.1 \%, 16.8 \%$ on average) and with larger differentiations among cultivars $(72.9 \%$ to $97.3 \%, 83.2 \%$ on average). Statistical and principal components analyses indicate that 12 leaf morphological characteristics are valuable for cultivar classification. ISSR markers present a precisely discriminatory power in tree peony cultivar classification without environmental influences. The cultivars with multiple flower forms, which makes it difficult to make judgment by means of a flower-form-based classification system, have been
\end{abstract} significantly characterized using leaf morphologv or ISSR markers.

Tree peonies (Paeonia suffruticosa Andrews) in China are deciduous subshrubs belonging to genus Paeonia L., section Moutan DC., family Paeoniaceae Rudolphi. They are important ornamental and resource plants(Hong and Pang, 1999). Tree peonies, designated the King of flowers, have been used as medicine for $>2000$ years and as ornamental flowers for about 1500 years in China. There are currently about 600 Chinese tree peony cultivars (Li, 1999; Wang, 1998). After introduction abroad since A.D. 724, several other unique cultivar groups have been bred in France, Britain, the United States, and other countries (Harding, 1993; Haw and Lauener, 1990; Kessenich, 1990; Li, 1999; Stern, 1946; Wang, 1998).

Received for publication 19 June 2004. Accepted for publication 11 Sept. 2004. This research was supported by the National Natural Science Foundation of China (grant30470177)andbyaKnowledgeInnovationProject from the ChineseAcademy of Sciences (Kscx2-sw-108). The authors acknowledgeYu-ping ZouandDr. Shi-liang Zhou for instructions of molecular marker experiments, Qi Wang in preparation of Fig.1, Xiao-qing Zhao for meaningful discussion on the taxonomic key, and thoughtful reviews of two anonymous referees.

${ }^{1}$ Corresponding author.

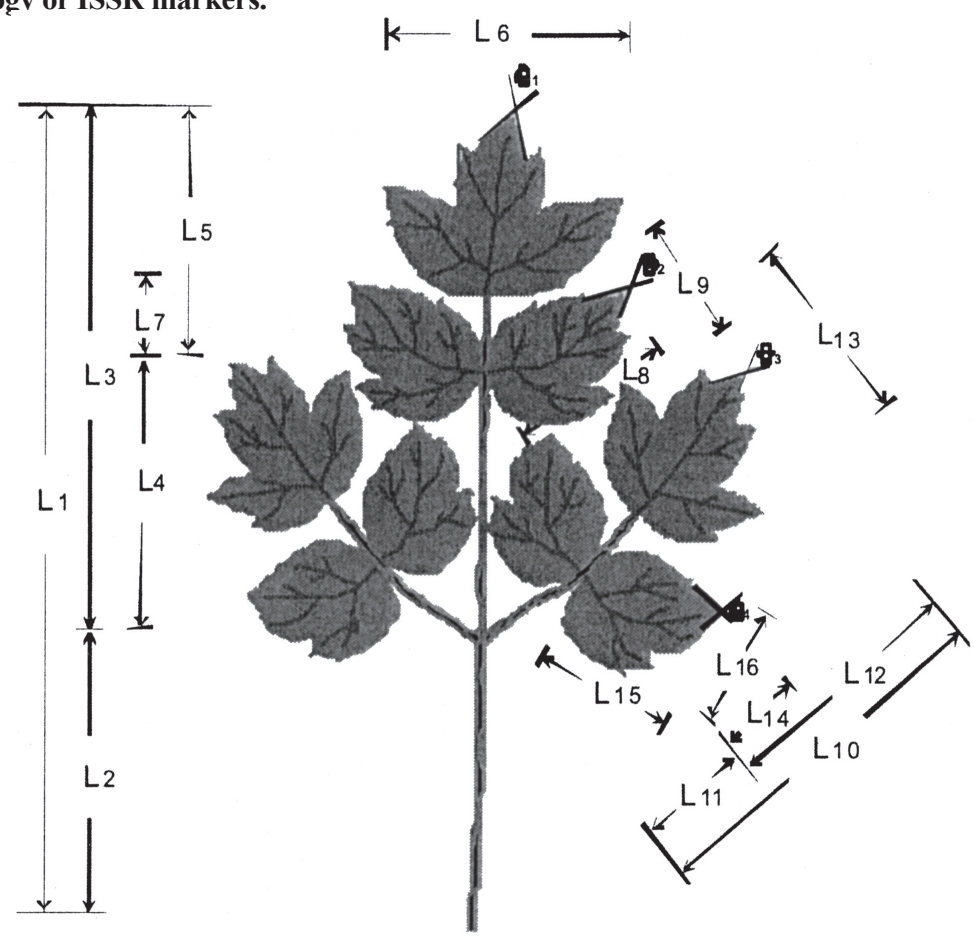

Fig. 1. Sketch map of measured parts of the biternately compound leaf. $\mathrm{L}_{1}=$ Full length of the biternately compound leaf. $\mathrm{L}_{2}=$ Main petiole length of the biternately compound leaf. $\mathrm{L}_{3}=$ Full length of the main compound leaf. $\mathrm{L}_{4}=$ Petiole length of the main compound leaf. $\left[\mathrm{L}_{5}\right]^{*}$ $=$ Terminal leaflet length of the main compound leaf. $\left[\mathrm{L}_{6}\right]^{*}=$ Terminal leaflet width of the main compound leaf. $\left[\mathrm{L}_{7}\right]^{*}=$ Petiole length of terminal leaflet of the main compound leaf. $\left[\theta_{1}\right]=$ Apex angle of the terminal leaflet of the main compound leaf. $\left[\mathrm{L}_{8}\right]^{*}=$ The first lateral leaflet length of the main compound leaf. $\left[\mathrm{L}_{9}\right]^{*}=$ The first lateral leaflet width of the main compound leaf. $\left[\theta_{2}\right]=$ Apex angle of the first lateral leaflet of the main compound leaf. $\left[\mathrm{L}_{10}\right]^{*}=$ Full length of the first lateral compound leaf. $\left[\mathrm{L}_{11}\right]^{*}$ $=$ Petiole length of the first lateral compound leaf. $\left[\mathrm{L}_{12}\right]^{*}=$ Terminal leaflet length of the first lateral compound leaf. $\left[\mathrm{L}_{13}\right]^{*}=$ Terminal leaflet width of the first lateral compound leaf. $\left[\mathrm{L}_{14}\right]^{*}$ $=$ Petiole length of terminal leaflet of the first lateral compound leaf. $\left[\theta_{3}\right]=$ Apex angle of the terminal leaflet of the first lateral compound leaf. $\left[\mathrm{L}_{15}\right]^{*}=$ The first lateral leaflet length of the first lateral compound leaf. $\left[\mathrm{L}_{16}\right]^{*}=$ The first lateral leaflet width of the first lateral compound leaf. $\left[\theta_{4}\right]=$ Apex angle of the first lateral leaflet of the first lateral compound leaf. The variables in brackets were used in principal components analysis (PCA). "Indicates the variables (with leaflet width replaced by the leaflet length to width ratio) used in cluster analysis. 
Chinese tree peony cultivars usually are classified based on characters of flower form and color. Yu and Yang (1962) and Yu (1998) reported 11 kinds of flower forms, Wang (1998) reported 16 flower forms, whereas $\mathrm{Li}$ (1999) believed that there are 14 flower forms. However, current flower-form based classification systems of Chinese tree peony cultivars could not provide satisfactory solutions concerning those plants with multiple flower forms or transitional flower forms. But, flower characters of tree peony cultivars are affected by environmental influences and developmental levels. Thus, judgment offlower forms depends on the observer ( $\mathrm{Li}, 1999$; Wang, 1998; Yu, 1998). Also, flower color is a horticultural trait that is difficult to apply extensively, as flowering period is 1 month each year. Precise and rapid cultivar identification methods are in urgent need in management of cultivar collections, as well as in tree peony breeding programs. Tree peony cultivars are propagated vegetatively following traditional propagation methods in China. Morphological variation between individual plants within a cultivar is small because of comparatively consistent cultivation conditions. However, leaf morphological characters are limited in classification of tree peony cultivars due to less detailed study of leaf morphology of cultivars. Leaf morphological characters usually are regarded as unimportant (secondary) characters or even are ignored (Li, 1999; Wang, 1998). For example, Chen and Ding (1992) did not mention leaf morphological characters when they conducted an evaluation on ornamental values of major characters of 47 tree peony cultivars using analytic hierarchy process (AHP). However, Hamada et al. (1989) found that the first component $\left(Z_{1}\right)$ is correlated highly with items showing foliage size according to multivariate analysis on 18 morphological characters (such as roots, stem, leaf and flower, etc.) of 26 Japanese tree peony cultivars. Yuan and Wang (2003) used the morphological characters of the third (herein designated no. 3) biternately compound leaf from the base of a shoot as one of the standard characters for analyzing the relationship of the wild species of Paeonia sect. Moutan subsect. Vaginatae F.C. Stern. Zhou etal. (2003) used 25 morphological

Table 1 . The mean values $(\mathrm{n} \geq 18)$ and standard deviations of twenty variables of the biternately compound leaf of eight tree peony cultivars

\begin{tabular}{|c|c|c|c|c|c|c|c|c|c|c|c|}
\hline \multirow[b]{3}{*}{ Cultivar } & \multicolumn{2}{|c|}{$\begin{array}{c}\text { Biternately } \\
\text { compound leaf }\end{array}$} & \multicolumn{9}{|c|}{ Main compound leaf } \\
\hline & \multirow[b]{2}{*}{$\begin{array}{l}\text { Full } \\
\text { length }\end{array}$} & \multirow{2}{*}{$\begin{array}{l}\text { Main } \\
\text { petiole } \\
\text { length }\end{array}$} & \multicolumn{6}{|c|}{ Terminal leaflet } & \multicolumn{3}{|c|}{ First lateral leaflet } \\
\hline & & & $\begin{array}{c}\text { Full } \\
\text { length }\end{array}$ & $\begin{array}{l}\text { Petiole } \\
\text { length }\end{array}$ & Length & Width & $\begin{array}{l}\text { Petiole } \\
\text { length }\end{array}$ & $\begin{array}{l}\text { Apex } \\
\text { angle }\end{array}$ & Length & Width & $\begin{array}{l}\text { Apex } \\
\text { angle }\end{array}$ \\
\hline 'Jiu Zui Yang Fei' & $38.2 \pm 6.6 \mathrm{ab}^{2}$ & $16.0 \pm 4.8 \mathrm{a}$ & $22.8 \pm 3.1 \mathrm{c}$ & $8.3 \pm 1.8 b$ & $11.1 \pm 1.3 \mathrm{c}$ & $9.7 \pm 2.4 \mathrm{c}$ & $3.4 \pm 1.0 \mathrm{c}$ & $52.6 \pm 7.6 \mathrm{c}$ & $11.5 \pm 1.2 \mathrm{~b}$ & $4.4 \pm 0.7 \mathrm{c}$ & $51.2 \pm 7.2 \mathrm{~d}$ \\
\hline 'Ling Hua Zhan Lu' & $38.7 \pm 6.2 \mathrm{a}$ & $12.3 \pm 3.2 \mathrm{bc}$ & $26.4 \pm 4.3 \mathrm{ab}$ & $9.3 \pm 3.4 b$ & $14.1 \pm 2.1 \mathrm{a}$ & $13.3 \pm 2.5 \mathrm{a}$ & $4.1 \pm 0.9 b$ & $53.1 \pm 4.6 \mathrm{c}$ & $13.5 \pm 0.9 \mathrm{a}$ & $5.3 \pm 0.7 b$ & $47.1 \pm 6.7 \mathrm{~d}$ \\
\hline 'Sheng Dan Lu' & $40.3 \pm 3.6 \mathrm{a}$ & $13.2 \pm 2.4 \mathrm{~b}$ & $27.4 \pm 2.1 \mathrm{a}$ & $9.3 \pm 0.9 b$ & $12.7 \pm 1.4 \mathrm{~b}$ & $12.1 \pm 3.2 \mathrm{ab}$ & $5.5 \pm 0.8 \mathrm{a}$ & $62.3 \pm 7.8 b$ & $13.0 \pm 1.5 \mathrm{a}$ & $5.2 \pm 0.8 b$ & $56.5 \pm 6.3 \mathrm{c}$ \\
\hline 'Shou An Hong' & $31.9 \pm 4.8 \mathrm{~d}$ & $10.0 \pm 3.2 \mathrm{~d}$ & $14.5 \pm 3.5 \mathrm{e}$ & $2.6 \pm 1.6 \mathrm{~d}$ & $9.5 \pm 0.9 \mathrm{~d}$ & $13.3 \pm 2.0 \mathrm{a}$ & $3.9 \pm 1.3 b$ & $83.6 \pm 7.4 \mathrm{a}$ & $10.3 \pm 0.8 \mathrm{~d}$ & $7.3 \pm 1.4 \mathrm{a}$ & $85.6 \pm 10.4 \mathrm{a}$ \\
\hline 'Wan Shi Sheng Se' & $35.3 \pm 5.6 b c$ & $14.2 \pm 3.6 \mathrm{ab}$ & $21.1 \pm 3.7 \mathrm{c}$ & $8.6 \pm 2.0 \mathrm{~b}$ & $10.6 \pm 1.5 \mathrm{c}$ & $8.3 \pm 1.9 \mathrm{~d}$ & $2.2 \pm 1.0 \mathrm{~d}$ & $49.4 \pm 6.5 \mathrm{c}$ & $10.2 \pm 1.6 \mathrm{c}$ & $4.1 \pm 1.2 \mathrm{c}$ & $49.7 \pm 5.9 \mathrm{~d}$ \\
\hline 'Wu Long Peng Sheng' & $33.6 \pm 3.5 \mathrm{~cd}$ & $10.6 \pm 1.9 \mathrm{dc}$ & $22.9 \pm 2.1 \mathrm{c}$ & $8.5 \pm 0.6 b$ & $9.2 \pm 1.3 \mathrm{~d}$ & $11.2 \pm 1.7 \mathrm{~b}$ & $5.3 \pm 0.9 a$ & $61.7 \pm 6.3 b$ & $8.0 \pm 1.0 \mathrm{e}$ & $5.6 \pm 0.9 b$ & $58.6 \pm 7.0 \mathrm{c}$ \\
\hline 'Ying Luo Bao Zhu' & $27.2 \pm 1.3 \mathrm{e}$ & $10.1 \pm 0.6 \mathrm{~d}$ & $16.6 \pm 1.1 \mathrm{~d}$ & $6.3 \pm 0.6 \mathrm{c}$ & $8.4 \pm 1.5 \mathrm{e}$ & $7.1 \pm 1.2 \mathrm{~d}$ & $2.4 \pm 0.4 \mathrm{~d}$ & $64.0 \pm 7.0 \mathrm{~b}$ & $7.7 \pm 0.6 \mathrm{e}$ & $3.6 \pm 0.4 \mathrm{~d}$ & $57.6 \pm 5.5 \mathrm{c}$ \\
\hline \multirow[t]{4}{*}{ 'Zhu Ye Qiu’' } & $41.2 \pm 4.9 \mathrm{a}$ & $16.1 \pm 3.9 \mathrm{a}$ & $25.2 \pm 2.6 \mathrm{~b}$ & $10.9 \pm 1.6 \mathrm{a}$ & $9.6 \pm 0.9 \mathrm{~d}$ & $12.2 \pm 2.8 \mathrm{ab}$ & $5.1 \pm 0.9 \mathrm{a}$ & $65.2 \pm 8.8 b$ & $10.1 \pm 0.9 \mathrm{c}$ & $7.0 \pm 1.2 \mathrm{a}$ & $63.4 \pm 10.8 b$ \\
\hline & \multicolumn{9}{|c|}{ The first lateral compound leaf } & & \\
\hline & \multicolumn{6}{|c|}{ Terminal leaflet } & \multicolumn{3}{|c|}{ The first lateral leaflet } & & \\
\hline & $\begin{array}{c}\text { Full } \\
\text { length }\end{array}$ & $\begin{array}{l}\text { Petiole } \\
\text { length }\end{array}$ & Length & Width & $\begin{array}{l}\text { Petiole } \\
\text { length }\end{array}$ & $\begin{array}{l}\text { Apex } \\
\text { angle }\end{array}$ & Length & Width & $\begin{array}{l}\text { Apex } \\
\text { angle }\end{array}$ & & \\
\hline 'Jiu Zui Yang Fei’' & $16.3 \pm 2.7 b c$ & $3.0 \pm 0.6 b$ & $11.8 \pm 1.4 \mathrm{~b}$ & $9.9 \pm 2.6 \mathrm{cb}$ & $2.5 \pm 1.0 \mathrm{c}$ & $50.4 \pm 5.3 c$ & $9.6 \pm 1.1 \mathrm{a}$ & $4.3 \pm 0.7 \mathrm{c}$ & $46.0 \pm 4.1 \mathrm{f}$ & & \\
\hline 'Ling Hua Zhan Lu' & $18.8 \pm 2.8 \mathrm{a}$ & $3.1 \pm 0.7 \mathrm{~b}$ & $13.3 \pm 1.0 \mathrm{a}$ & $10.4 \pm 3.3 b$ & $2.9 \pm 1.2 \mathrm{cb}$ & $48.7 \pm 5.1 \mathrm{c}$ & $8.8 \pm 1.6 b$ & $4.7 \pm 0.8 \mathrm{c}$ & $55.3 \pm 7.1 \mathrm{de}$ & & \\
\hline 'Sheng Dan Lu' & $18.0 \pm 2.7 \mathrm{ab}$ & $2.6 \pm 0.9 b$ & $12.5 \pm 1.4 \mathrm{ab}$ & $8.8 \pm 2.2 \mathrm{c}$ & $3.3 \pm 1.3 b$ & $59.3 \pm 5.8 b$ & $7.5 \pm 1.3 \mathrm{c}$ & $4.3 \pm 0.8 \mathrm{c}$ & $70.2 \pm 7.1 b$ & & \\
\hline 'Shou An Hong' & $13.3 \pm 2.9 \mathrm{~d}$ & $1.6 \pm 0.5 \mathrm{c}$ & $10.1 \pm 1.2 \mathrm{~d}$ & $10.0 \pm 2.2 \mathrm{cb}$ & $2.5 \pm 1.3 \mathrm{c}$ & $81.3 \pm 9.2 \mathrm{a}$ & $7.1 \pm 0.7 \mathrm{c}$ & $7.1 \pm 0.9 \mathrm{a}$ & $85.1 \pm 9.2 \mathrm{a}$ & & \\
\hline 'Wan Shi Sheng Se' & $14.0 \pm 3.3 \mathrm{~d}$ & $2.8 \pm 0.9 b$ & $9.9 \pm 1.6 \mathrm{~cd}$ & $7.5 \pm 2.3 \mathrm{~d}$ & $1.8 \pm 1.0 \mathrm{~d}$ & $47.9 \pm 8.8 \mathrm{c}$ & $7.2 \pm 1.4 \mathrm{c}$ & $4.3 \pm 0.8 \mathrm{c}$ & $51.0 \pm 6.6 \mathrm{e}$ & & \\
\hline 'Wu Long Peng Sheng' & $15.7 \pm 2.4 \mathrm{c}$ & $3.5 \pm 0.5 \mathrm{a}$ & $8.3 \pm 1.0 \mathrm{e}$ & $9.2 \pm 1.7 \mathrm{cb}$ & $4.2 \pm 0.9 \mathrm{a}$ & $60.9 \pm 5.3 b$ & $5.9 \pm 1.2 \mathrm{~d}$ & $5.6 \pm 1.2 b$ & $59.5 \pm 6.7 \mathrm{~cd}$ & & \\
\hline 'Ying Luo Bao Zhu' & $10.8 \pm 1.2 \mathrm{e}$ & $1.6 \pm 0.4 \mathrm{c}$ & $7.5 \pm 0.8 \mathrm{f}$ & $5.3 \pm 0.8 \mathrm{e}$ & $1.8 \pm 0.4 \mathrm{~d}$ & $61.0 \pm 5.0 \mathrm{~b}$ & $5.3 \pm 0.5 \mathrm{~d}$ & $3.4 \pm 0.3 \mathrm{~d}$ & $67.2 \pm 7.2 b$ & & \\
\hline 'Zhu Ye Qiu' & $17.2 \pm 2.7 \mathrm{abc}$ & $2.8 \pm 1.1 b$ & $10.1 \pm 1.4 \mathrm{c}$ & $11.8 \pm 1.7 \mathrm{a}$ & $4.4 \pm 1.1 \mathrm{a}$ & $61.9 \pm 5.2 \mathrm{~b}$ & $8.4 \pm 1.1 b$ & $6.8 \pm 1.2 \mathrm{a}$ & $62.2 \pm 7.5 \mathrm{c}$ & & \\
\hline
\end{tabular}

${ }^{\mathrm{z}}$ Means followed by the same letter in the same column are not significantly different at 0.05 level. Twelve variables (after leaflet width was replaced by the leaflet length to width ratio) were used in cluster analysis.

Table 2. Variation of leaf morphological characters among cultivar differentiation and within cultivars. See Fig. 1 for definitions of the characteristics.

\begin{tabular}{|c|c|c|c|c|c|c|c|c|}
\hline \multirow[b]{2}{*}{ Characteristic } & \multicolumn{3}{|c|}{ Variance component } & \multicolumn{3}{|c|}{ Percent of variance component } & \multirow{2}{*}{$\begin{array}{l}\text { Differentiation } \\
\text { coefficients } \\
\text { among cultivars } \\
\text { Vst }(\%)\end{array}$} & \multirow{2}{*}{$\begin{array}{c}\text { Variation } \\
\text { coefficient } \\
\text { within cultivar } \\
V(\%)\end{array}$} \\
\hline & $\begin{array}{c}\text { Among } \\
\text { cultivars } \\
\sigma_{\mathrm{t}}^{2} / \mathrm{s}\end{array}$ & $\begin{array}{c}\text { Within } \\
\text { cultivars } \\
\sigma_{\mathrm{t}}^{2}\end{array}$ & $\begin{array}{c}\text { Random } \\
\text { errors } \\
\sigma_{\mathrm{e}}^{2}\end{array}$ & $\begin{array}{c}\text { Among } \\
\text { cultivars } \\
P_{t} / s\end{array}$ & $\begin{array}{c}\text { Within } \\
\text { cultivars } \\
P_{t}\end{array}$ & $\begin{array}{c}\text { Random } \\
\text { errors } \\
P_{\mathrm{e}} \\
\end{array}$ & & \\
\hline $\mathrm{L}_{1}$ & 20.221 & 9.070 & 17.479 & 43.2 & 19.5 & 13.2 & 69.0 & $4.8-17.3$ \\
\hline $\mathrm{L}_{2}^{1}$ & 5.622 & 0.558 & 9.186 & 19.4 & 74.3 & 16.1 & 91.0 & $5.9-32.0$ \\
\hline $\mathrm{L}_{3}^{2}$ & 19.911 & 3.982 & 6.265 & 37.4 & 6.2 & 46.6 & 83.3 & $6.6-24.1$ \\
\hline $\mathrm{L}_{4}^{3}$ & 5.967 & 0.997 & 2.504 & 36.6 & 19.4 & 11.4 & 85.7 & $7.1-61.5$ \\
\hline $\mathrm{L}_{5}^{4}$ & 3.579 & 0.872 & 0.718 & 3.6 & 76.5 & 41.9 & 80.4 & $9.4-17.9$ \\
\hline $\mathrm{L}_{6}^{3}$ & 4.917 & 1.644 & 2.584 & 59.8 & 14.3 & 48.4 & 74.9 & $15.0-26.4$ \\
\hline $\mathrm{L}_{7}^{0}$ & 1.468 & 0.354 & 0.442 & 66.0 & 9.2 & 12.4 & 80.6 & $14.5-45.5$ \\
\hline$\theta_{1}^{\prime}$ & 112.077 & 9.389 & 29.314 & 13.2 & 67.8 & 39.2 & 92.3 & $8.7-14.4$ \\
\hline $\mathrm{L}_{8}$ & 4.386 & 0.823 & 0.528 & 20.8 & 17.0 & 72.6 & 84.2 & $6.7-15.7$ \\
\hline $\mathrm{L}_{9}^{\circ}$ & 1.544 & 0.386 & 0.346 & 63.0 & 15.2 & 9.3 & 80.0 & $11.1-29.3$ \\
\hline$\theta_{2}$ & 143.505 & 3.998 & 34.369 & 10.5 & 78.9 & 18.2 & 97.3 & $9.5-17.0$ \\
\hline $\mathrm{L}_{10}^{2}$ & 6.449 & 2.322 & 4.264 & 26.4 & 2.2 & 58.6 & 73.5 & $11.1-23.6$ \\
\hline $\mathrm{L}_{11}$ & 0.444 & 0.165 & 0.450 & 69.2 & 18.9 & 8.9 & 72.9 & $14.3-39.3$ \\
\hline $\mathrm{L}_{12}^{11}$ & 3.945 & 0.740 & 0.901 & 16.9 & 49.5 & 32.4 & 84.2 & $7.5-16.2$ \\
\hline $\mathrm{L}_{13}^{12}$ & 3.593 & 0.880 & 3.230 & 13.9 & 17.8 & 62.4 & 80.3 & $14.4-31.7$ \\
\hline $\mathrm{L}_{14}^{13}$ & 0.901 & 0.231 & 0.731 & 53.8 & 32.7 & 9.5 & 79.6 & $21.4-55.6$ \\
\hline$\theta_{3}^{14}$ & 112.268 & 14.348 & 28.111 & 18.0 & 41.9 & 28.1 & 88.7 & $8.2-18.4$ \\
\hline $\mathrm{L}_{15}^{3}$ & 1.987 & 0.303 & 1.098 & 28.3 & 15.6 & 72.6 & 86.8 & $9.4-20.3$ \\
\hline $\mathrm{L}_{16}^{13}$ & 1.627 & 0.248 & 0.731 & 64.8 & 42.5 & 8.9 & 86.8 & $8.8-21.4$ \\
\hline$\theta_{4}$ & 145.778 & 17.922 & 36.976 & 15.6 & 70.6 & 18.4 & 89.1 & $8.9-12.9$ \\
\hline Mean & & & & 34.0 & 34.5 & 31.5 & 82.2 & \\
\hline
\end{tabular}



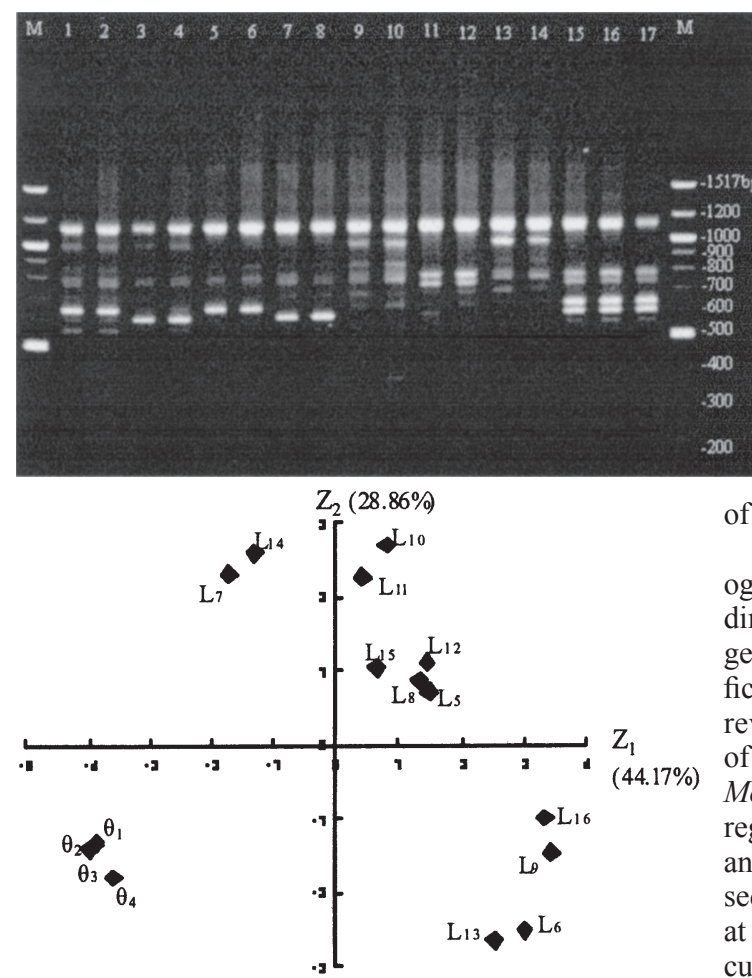

Fig. 3. Scatter diagram of weight of two principal components $\left(Z_{1}, Z_{2}\right)$ to 16 morphological character values. $Z_{1}=$ the first principal component. $Z_{2}=$ the second principal component. See Fig. 1 for definitions of the characteristics.

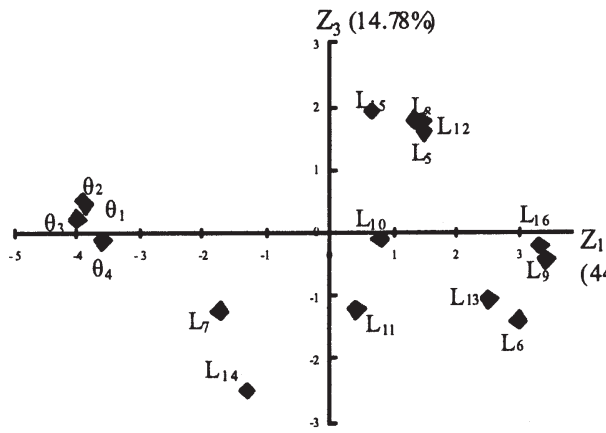

Fig. 4. Scatter diagram of weight of two principal components $\left(\mathrm{Z}_{1}, \mathrm{Z}_{3}\right)$ to 16 morphological character values. $Z_{1}=$ the first principal component. $\mathrm{Z}_{3}=$ the third principal component. See Fig. 1 for definitions of the characteristics. $\mathrm{Z}_{1}$ (44.7\%)

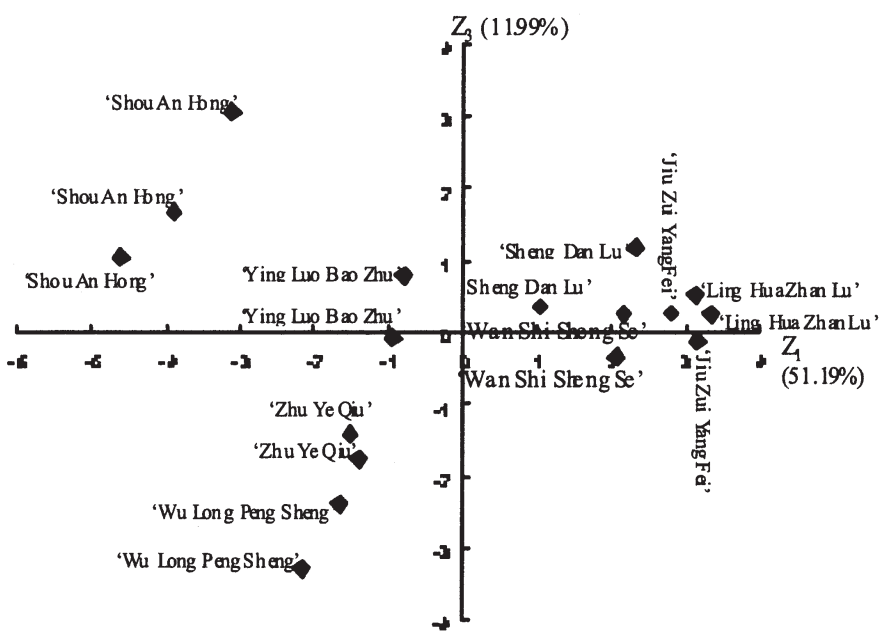

Fig. 6. Scatter diagram on $Z_{1}-Z_{3}$ plane of 17 individual plants representing eight tree peony cultivars by the component scores.

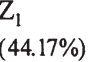

Fig. 2. Genomic DNA ISSR fingerprinting pattern obtained from the 17 individuals representing 8 tree peony cultivars with primer issr-04. Sample numbers: 1 and $2=$ 'Zhu Ye Qiu', 3 and $4=$ 'Wu Long Peng Sheng', 5 and $6=$ 'Ying Luo Bao Zhu', 7 and $8=$ 'Jiu Zui Yang Fei', 9 and 10 = 'Sheng Dan Lu', 11 and 12 = 'Ling Hua Zhan Lu', 13 and 14 = 'Wan Shi Sheng Se', and 15,16 , and $17=$ 'Shou An Hong'. $\mathrm{M}=$ the 100-bp DNA ladder.

characters including leaflet shape and apex to analyze phylogeny of Paeonia section Moutan.

Advances in molecular biotechnology have enabled us to use information directly from DNA in evaluation of genetic resources of plants and classification of cultivars. Sang et al. (1997) revealed phylogenetic relationship of five wild species of Paeonia sect. Moutan using sequences of rDNAITS region, mat $\mathrm{K}$ gene, $\operatorname{trn} \mathrm{L}-t r n \mathrm{~F}$ region and $p s b \mathrm{~A}-t r n \mathrm{H}$ region, but these gene sequences presented minor variations at species level, without resolution at cultivar level. Pei et al. (1995) analyzed relationship between Paeonia suffruticosa subsp. spontanea (Rehd.) S.G. Haw et L. A. Lauener (7 individual plants) and $P$. rockii (S.G. Haw et L.A. Lauener) T. Hong et J.J. Li (7 individual plants) using randomly amplified polymorphic DNA (RAPD) markers. Hosoki et al. (1997) analyzed the relationship between 14 Japanese tree peony cultivars, 5 yellow flowering hybrid cultivars, $P$. lutea Delavayi ex Franch. and P. lactiflora Pall. using RAPD markers. Zou et al. (1999) analyzed genetic relationship of eight species in Paeonia sect. Moutan based on RAPD data. Chen et al. (2001, 2002) discussed genetic relationships of around 30 tree peony cultivars based on RAPD markers indicating that RAPD fingerprinting technique was able to reveal genetic relationship of tree peony cultivars that are difficult to describe using morphological characters or flower color. However, most studies on tree peony wild species and cultivars using
RAPD marker system are still at the stage of optimizing experimental conditions or exploring methods, although some tendencies have been revealed. Similar to RAPD markers, but with higher polymorphism and reproducibility, intersimple sequence repeat (ISSR) markers have been applied extensively in studies on origin, evolution and genetic relationship of plants and cultivated varieties, and molecular marker-assisted breeding in recent years (Godwin et al., 1997). The objective of this paper is to analyze and evaluate the feasibility of leaf morphology and ISSR markers in classification of tree peony cultivars.

\section{Materials and Methods}

Materials. Seventeen plants, 12 to 15 years old, representing eight Chinese tree peony cultivars ('Jiu Zui Yang Fei', 'Ling Hua Zhan Lu', 'Sheng Dan Lu', 'Shou An Hong', 'Wan Shi Sheng Se', 'Wu Long Peng Sheng', 'Ying Luo Bao Zhu' and 'Zhu Ye Qiu') under cultivation in Beijing Botanical Garden, Chinese Academy of Sciences, were used in this study (see Table 1 and the taxonomic key). The biternately compound leaf of all of the cultivars typically is comprised of nine leaflets (Fig. 1). For gDNA extraction, leaves were collected in spring before flowering time and dried using silica gel.

Leaf morphological data. Morphological data were collected on 20 morphological characters from 18 to 27 biternately compound leaves (nos. 3, 4, and 5 from the base of a shoot) from 6 to 9 shoots sampled at the middle crown of the plants for each cultivar when the leaves reached matured sizes by the end of June. Usually, there are seven to nine biternately compound leaves on each shoot. The part of the compound leaf comprising of the upper three leaflets is defined as the main compound leaf; the three leaflets on the right side of the central axis of the main petiole is defined as the first lateral compound leaf; and the three leaflets on the left side as the second lateral compound leaf. According to preobservations, it was found that the lower two leaflets in each compound leaf are symmetric, and the first and second compound leaves are also symmetric (unpublished data). Thus, data from the terminal and the first lateral leaflets of the main and second compound leaves for each biternately compound leaf were used in

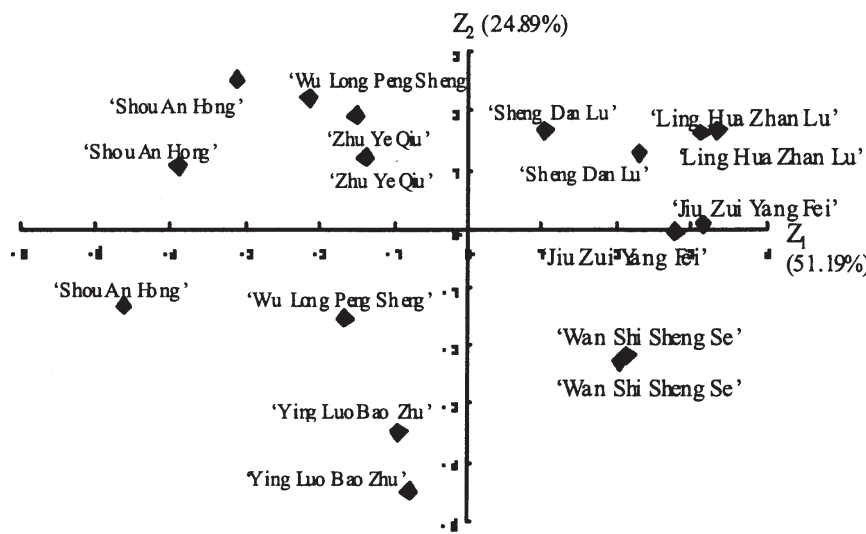

Fig. 5. Scatter diagram on $Z_{1}-Z_{2}$ plane of 17 individual plants representing eight tree peony cultivars by the component scores. 


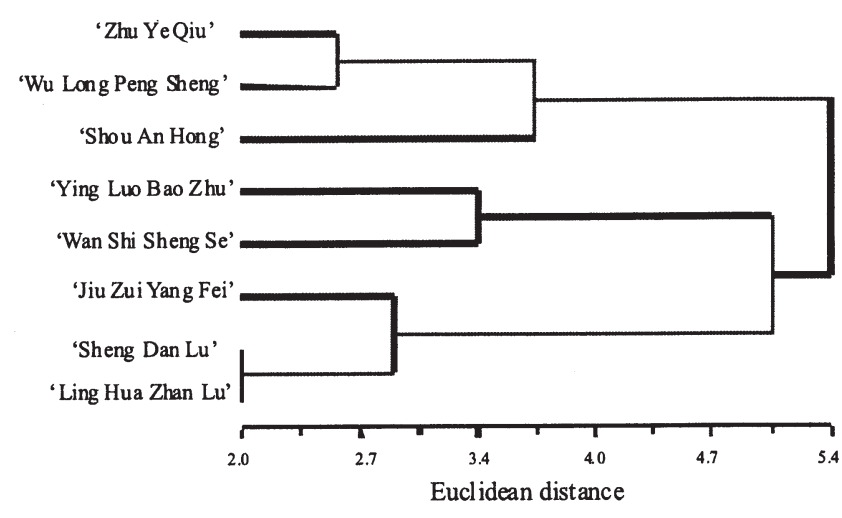

Fig.7. Dendrogram of eight tree peony cultivars based on leaf morphological data by UPGMA method.

$\min ; 8$ min at $72{ }^{\circ} \mathrm{C}$ forfinal extension; and then ramped to $4{ }^{\circ} \mathrm{C}$ to hold the reaction. Amplification products were resolved simultaneously on $2 \%$ agarose gels run in $1 \times$ TBE buffer at 3 $\mathrm{V} \cdot \mathrm{cm}^{-1}$ for $3.5 \mathrm{~h}$ and were stained with ethidium bromide. Banding patterns

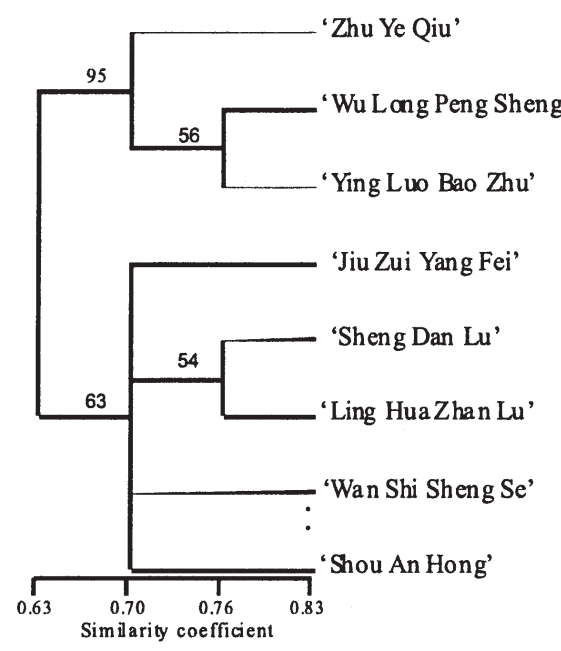

Fig. 8. Bootstrap 50\% majority-rule consensus tree of eight tree peony cultivars based on ISSR analysis using UPGMA cluster method. The numbers above branches are bootstrap values (\%) of 1000 replications.

further analysis. A biternately compound leaf includes three compound leaves totaling 9 leaflets (Fig. 1).

DNA extraction and primer screening. gDNAs were extracted from leaves using improved CTAB extraction method (Doyle and Doyle, 1987; Wang et al., 1996) with polysaccharides removed using $2 \mathrm{~mol} / \mathrm{L} \mathrm{NaCl}$ solution. Six of seventy ISSR primers were confirmed to be effective to produce clear and reproducible band patterns. The codes, sequences and annealing temperatures of the primers formally used in PCR amplification are 1) ISSR-01: (CA) RG, $50{ }^{\circ} \mathrm{C}$; 2) ISSR-03: (CT) ${ }_{8} \mathrm{RC}, 52{ }^{\circ} \mathrm{C}$; 3 ) ISSR-04: (CT) ${ }_{8} \mathrm{RG}, 52{ }^{\circ} \mathrm{C}$; 4) ISSR-05: (CTC) $)_{4} \mathrm{RC}, 48{ }^{\circ} \mathrm{C}$; 5) ISSR-13: (AGTG) $)_{4}, 48^{\circ} \mathrm{C}$; 6) ISSR-14: (GACA) ${ }_{4}, 46$ ${ }^{\circ} \mathrm{C}$. In the primer sequences, $\mathrm{R}=\mathrm{A} / \mathrm{G}$.

ISSR-PCR amplification. ISSR-PCR amplifications were performed in a $T$-personal 48 thermal cycler (Biometra made in Germany). Each $25 \mu \mathrm{L}$ amplification reaction consisted of 25 ng DNA, 10 mM Tris- $\mathrm{HCl}$ (pH8.3), $50 \mathrm{mM}$ $\mathrm{KCl}, 2.0 \mathrm{mM}$ of $\mathrm{MgCl}_{2}, 1 \mathrm{mM}$ of each dNTP, $0.2 \mu \mathrm{M}$ of primer and 1 unit of Taq DNA polymerase (TaKaRa Biotechnology (Dalian) Co., Ltd.). ISSR-PCR amplification program is as follows: $94{ }^{\circ} \mathrm{C}$ for $3 \mathrm{~min}$; 38 cycles of $94^{\circ} \mathrm{C}$ for $40 \mathrm{~s}$, Ta (annealing temperature of the corresponding ISSR primer) for $15 \mathrm{~s}, 72^{\circ} \mathrm{C}$ for 1.5 were documented and photographed with the 2000 Gel Documentation System (BIO-RAD Laboratories, Segrate (Milan), Italy). The 100bp Ladder DNA size marker (100 to $1517 \mathrm{bp}$ ) was from Sigma Chemical Co.

Data analysis. On the basis of preobservations, a data set of the 20 characters was collected consisting of 4896 data. ANOVA and Duncan's test were used for principal components analysis (PCA). Sixteen characters presented significant differences $(P<0.001$, in multiple range test, nested analysis of variances and PCA were performed using SAS software package (version 6.12). According to Ge et al. (1988), differentiation coefficient of each morphological character among cultivars $V_{s t}$ is defined as $V_{s t}=\left(\sigma_{t}^{2} / s\right) /\left(\sigma_{t}^{2}+\sigma_{t}^{2} / s\right)$, indicating the total percentage of morphological variation among cultivars, where $\sigma_{t}^{2} / \mathrm{s}$ represents variacter among cultivars; $\sigma_{t}^{2}$ represents variance component of each morphological character within cultivars; $\sigma_{e}^{2}$ represents random error. Variance coefficient of each morphological character was computed as standard error divided by mean value. Twelve characters with significant discriminatory ability were selected based on the results of PCA for cluster analysis that was performed with NTSYS-pc version 2.02a (Rohlf, 1997) using the unweighted pairgroup method. Arithmetic averages (UPGMA) were used after leaflet width was replaced by the leaflet length: width ratio (data not shown). All of the data were standardized so as to analyze the relationship of cultivars.

Only PCR fragments (bands) of 200 to 1500 bp were calculated with Quantity One software(Version 4.2.1) for molecular weights. ISSR markers were scored on the basis of the presence (1) or absence (0) of band at each locus of the samples. A 0 and 1 matrix was created for computing Nei-Li distances. A phylogenetic tree was generated using UPGMA method with PAUP 4.0b10 software (Swofford, 2001). MXCOMP program was used to compare Euclidean morphological and ISSR distances (Rohlf, 1997).

\section{Results}

Analysis of leaf morphology. Preobservations indicated that the morphological characters of nos. 3, 4, and 5 biternately compound leaves from the base of a shoot at the middle crown of a plant presented a good stability. all analyses) between cultivars tested. Duncan's ance component of each morphological char-
Although there exist large variations of leaf morphology among/within tree peony cultivars. Table 1 shows the mean values of 20 leaf morphological characters of the biternately compound leaf of eight tree peony cultivars. Four characters were judged as unsuitable factors in cultivar classification and excluded from the dataset in PCA, since their numerical values (Table 1) were similar among cultivars and the differences between cultivars (Table 1) were not significant according to statistical analysis, and also, variance coefficients (Table 2 ) and random errors of variance component (Table 2) are larger. These included the full length of the biternately compound leaf $\left(\mathrm{L}_{1}\right)$, the main petiole length of the biternately compound leaf $\left(\mathrm{L}_{2}\right)$, the full length of the main compound leaf $\left(\mathrm{L}_{3}\right)$ and the petiole length of the main compound leaf $\left(\mathrm{L}_{4}\right)$. The remaining 16 leaf morphological characters with smaller within cultivar variations and larger among cultivar differentiations (Table 1 and Table 2) were considered to be useful for evaluation of discriminatory ability of tree peony cultivars. PCA results of the sixteen characters indicate that three principal components $\left(Z_{1}, Z_{2}\right.$, and $Z_{3}$ ) could reveal $87.8 \%$ of the total variation of leaf morphology. $Z_{1}$ (with a contribution of $44.17 \%$ ) was correlated highly with the four variables of leaflet width (i.e., $\mathrm{L}_{6}, \mathrm{~L}_{9}, \mathrm{~L}_{13}$, and $\mathrm{L}_{16}$ ) and correlated moderately with the three variables of leaflet length $\left(\mathrm{L}_{5}, \mathrm{~L}_{8}\right.$, and $\left.\mathrm{L}_{12}\right) . \mathrm{Z}_{2}$ (with a contribution of $28.86 \%$ ) was correlated highly with the three variables of petiole length $\left(\mathrm{L}_{7}, \mathrm{~L}_{11}\right.$, and $\left.\mathrm{L}_{14}\right)$ and the full length of the first lateral compound leaf $\left(\mathrm{L}_{10}\right)$, and also correlated moderately with the four variables of leaflet length $\left(\mathrm{L}_{5}, \mathrm{~L}_{8}, \mathrm{~L}_{12}\right.$, and $\left.\mathrm{L}_{15}\right)$. $\mathrm{Z}_{3}$ (with a contribution of $14.78 \%$ ) was correlated highly with the four variables of leaflet length $\left(\mathrm{L}_{5}, \mathrm{~L}_{8}, \mathrm{~L}_{12}\right.$, and $\mathrm{L}_{15}$ )(Figs. 3 and 4). No correlations were found between the apex angles $\left(\theta_{1}, \theta_{2}, \theta_{3}\right.$, and $\left.\theta_{4}\right)$ and the three principal components. Thus, apex angles were excluded from the dataset used for cluster analysis. In scatter diagram on $Z_{1}-Z_{2}$ plane (Fig. 5), two individuals of 'Wu Long Peng Sheng' were grouped loosely. However, they were grouped closely in scatter diagram on $Z_{1}-Z_{3}$ plane (Fig. 6) indicating that there existed leaf morphological variations within cultivar 'Wu Long Peng Sheng'. Whereas the other individual plants were positioned closely with each other by cultivar. Twelve leaf morphological characters with smaller variations within cultivars $(2.7 \%$ to $27.1 \%, 16.8 \%$ on the average) and with larger differentiations among cultivars $(72.9 \%$ to $97.3 \%, 83.2 \%$ on the average) were selected by screening using PCA for cluster analysis of the relationship of the cultivars. At the Euclidean distance value of 4.0, eight cultivars were divided into 3 groups (Fig. 7). Cultivars positioned in one group can be regarded as morphologically closer cultivars. Group I consisted of ' Zhu Ye Qiu', 'Wu Long Peng Sheng' and 'Shou An Hong'. Group II included 'Ying Luo Bao Zhu' and 'Wan Shi Sheng Se'. Group III was comprised of 'Jiu Zui Yang Fei', 'Sheng Dan Lu' and 'Ling Hua Zhan Lu'.

ISSR marker analysis. Eighty-one bands, including 62 polymorphic bands, were detected 
by the six selected primers. ISSR fingerprinting patterns were same within a cultivar (Fig. 2), identical with traditional vegetative propagation methods of Chinese tree peony cultivars. In Fig. 8, eight cultivars were divided into two branches, the branch containing ' $\mathrm{Zhu} Y \mathrm{Ye}$ Qiu', 'Wu Long Peng Sheng', and 'Ying Luo Bao Zhu' obtained $95 \%$ bootstrap support, and the other branch consisting of five cultivars obtained $63 \%$ bootstrap support.

A taxonomic key to the eight tree peony cultivars.

1. Blunt apex of leaflets with an angle of $80^{\circ}$ to $100^{\circ}$. A triploid cultivar. Leaflet broadly ovate and thick. Type of the compound leaf: large-sized circular leaf. Surface deep green. Dense, short vellus hairs on the lower side of blade. Stiff petiole, with a large diameter and light yellowish green color. Axillary bud, conical, with deep purplish-brown tip. Plant 98-104 cm tall, erect, with fewer branches. Roots, deep purplish-red. Flower, crown-like form, deep purplish-red color................... 'Shou An Hong'

1. Acuminated apex of leaflets with an angle of $<80^{\circ}$. A diploid cultivar.

2. Leaflets large-sized and thick. Type of the compound leaf: large-sized long leaf. Terminal leaflets longovate. Lateral leaflets lanceolate, mostly without notches. Surface dark green, obliquely ascending, leaf posture neat, no vellus hairs on the lower side. Apex angles of leaves range from $55^{\circ}$ to $70^{\circ}$. Bud conical, taper and light green. Plant 104-115 cm tall, semi-expanding type. Pedicels shorter, with a larger diameter, flowers partially shaded by leaves. Growth extremely vigorous. Flower, crown proliferate form, pinkish and purplish red color................. 'Sheng Dan Lu'

\section{Leaflets not thick.}

3. The length:width ratio of the terminal leaflet in the main compound leaf obviously lower than 1. 4. Type of the compound leaf: small-sized long leaf. Lateral leaflets with deep notches. Leaflet apex angle about $62-65^{\circ}$ on average. Leaflet surface deep green, with dense and short vellus hairs on the vein ribs of the lower side. Scaly bud conical, green or light purplish green, with purplish red tip. Occasionally, on the lignified part of the current year shoot which just experienced flower blooming, the uppermost scaly bud attached at the position about $0.5 \mathrm{~cm}$ above the axil. Plant $102-133 \mathrm{~cm}$ tall, erect. Internode longer. Leaves fall earlier. Flower smaller, silk-ball like form and purplish-red color. 'Zhu Ye Qiu'

4. Type of the compound leaf: middle-sized long leaf. Leaflets nearly elliptic or oblong, lateral leaflets with notches, keep straight, obliquely ascending, leaf posture neat. Apex angle of each leaflet considerably identical, ca. $60^{\circ}$. Green scaly bud short and conical. Leaf surface deep green, with some short vellus hairs on vein ribs of the lower side. Commonly, on the lignified part of the current year shoot which just experienced flower-blooming, the uppermost scaly bud attached at the position about $0.5 \mathrm{~cm}$ above the axil. Plant 83-106 cm tall, erect. Sprouting vigorously. Flower relatively larger, with hundred proliferate form, purplish red color..................'Wu Long Peng Sheng'

\section{The length:width ratio of the terminal leaflets higher than 1 .}

5. Type of the compound leaf: small-sized long leaf. Leaflets small-sized, long elliptic and light green Petiole slender and green. Internode shorter. Most lateral leaflets have no incision. Basal part of the lower side possesses short vellus hairs. Scaly bud conical, taper, with greenish creamy white color. On the lignified part of the current year shoot which just experienced flower-blooming, the uppermost scaly bud attached at the tip of a super-short branch (about $0.5 \mathrm{~cm}$ long) protruded from the axil. Usually, $3-6$ newly produced small leaflets at the axil. Plant medium-height or dwarf, semi-expanding, branches and leaves compact relatively. Lateral roots many. Sprouting vigorously. Flower, crown proliferate form and light red color...................'Ying Luo Bao Zhu'

5. Type of the compound leaf: middle-sized or large-sized long leaf.

6. Diverse postures (obliquely ascending, right angle attachment or pendulous) of leaf or leaflet, branches relatively sparse, internode long, presented a so-called "dancer's posture" as an overall outward appearance. Large-sized long leaf. Leaflet longer, light green. Two new leaflets (one of them often withered) emerged usually at the outside of the axillary bud base. Short vellus hairs sparse or absent on the lower side of leaflets. Scaly bud, blunt conical, pale purple. Sprouting weekly. Plant 104-124 cm tall, expanding type. Multiple flower form cultivar, producing flowers with lotus- or anemone-, sometimes crown-like form and pinkish purple color.................. 'Jiu Zui Yang Fei'

6. Leaves obliquely ascending regularly in general, no hairs on the lower side. Scaly bud conical, taper, light green. Sprouting vigorously.

7. Leaflet surface green, petiole short $(1.8-2.2 \mathrm{~cm})$. Middle-sized to large-sized long leaf. Lateral leaflets of the main compound leaf, narrow and long lanceolate, mostly entire. Plant medium-height or dwarf (58-64 cm), expanding type, leaf posture neat. Flower, crown-like form, light purple color................. 'Wan Shi Sheng Se'

7. Surface light green. Petiole longer $(2.9-4.1 \mathrm{~cm})$ and slender. Lateral leaflet, broadly lanceolate, with many notches. Middle-sized long leaf. Axillary bud adnate to the branch commonly. Plant medium-height to tall (85-115 cm), semi-expanding type. Flower, hundred proliferate form, pinkish purple color.................'Ling Hua Zhan Lu'

Notes: Bud shape and color were observed at the end of September. Flower form is the representative one of each cultivar. Type of the biternately compound leaf was determined following the definitions of Wang (1998). the two methods, but their close relationship was supported only by leaf morphological data. The three cultivars named 'Jiu Zui Yang Fei', 'Sheng Dan Lu', and 'Ling Hua Zhan Lu' belong to a pinkish-purple color series (Wang 1998). They could be discriminated and grouped together using either of the two datasets, 'Wu Long Peng Sheng' and 'Ling Hua Zhan Lu', which all produce hundred proliferate flower forms, could be characterized using either of the two datasets, and so did in the case of 'Ying Luo Bao Zhu' and 'Sheng Dan Lu' which all produce crown proliferate flower forms, as well as in the case of "Wan Shi Sheng Se', 'Shou An Hong', and 'Jiu Zui Yang Fei' which all can produce crown-like flower forms. Also, 'Jiu Zui Yang Fei' with multiple flower forms (lotus or anemone, sometimes crown-like flower form) was significantly characterized using either of the two datasets, although it is difficult to make judgment using the flower-form based classification system. However, correlation between Euclidean morphological and ISSR molecular distances was low $(r=0.3569, p=0.045)$.

\section{Discussion and Conclusion}

'Shou An Hong', the only triploid (Li et al., 1982) known among diploid Chinese tree peony cultivars is separated easily. It possessed unique leaf morphological characters, such as leaflet large-sized, thick and orbicular, with an apex angle of 80 to $100^{\circ}$, with significantly dense and short vellus hairs on the lower side. Shared characteristics among 'Shou An Hong', 'Zhu Ye Qiu', and 'Wu Long Peng Sheng' included that the terminal leaflet length of the main compound leaf $\left(\mathrm{L}_{5}\right)$ was obviously smaller than the width $\left(\mathrm{L}_{6}\right)$, explaining why they were grouped closely according to morphological distances (Fig. 7). However, they possessed different leaflet shape (see the taxonomic key). 'Ying Luo Bao Zhu' has small leaflets, and its uppermost scaly bud attaching at the tip of a super-short branch (about $0.5 \mathrm{~cm}$ long) protruded from the axil on the lignified part of the current year shoot which just experienced flower-blooming. 'Jiu Zui Yang Fei' possesses relatively sparse (fewer) branches, long internodes and diverse postures (obliquely ascending, right angle attachment or pendulous) of leaves or leaflets, just as the meaning of the cultivar's name in memory of the dancing posture-Drunken Beauty - of Yu huan Yang, the famous imperial concubine after she became tipsy in Tang Dynasty in ancient China. 'Sheng Dan Lu' has large-sized and thick leaflets. Terminal leaflets are long-ovate and lateral leaflets lanceolate, mostly without notches. Surface dark green, obliquely ascending, leaf posture neat. Flowers are often shaded partially or slightly by leaves at anthesis due to its short pedicels. These are distinct characteristics for recognition. 'Wan Shi Sheng Se' and 'Ling Hua Zhan Lu' could be segregated using leaf color, shape and petiole length as described in the taxonomic key. Petiole color was comparatively not so effective (significant) as the above-mentioned characters when cultivar identification was conducted by eye. 
'Mei Gui Hong' was bred through isolation and grafting of bud mutation of 'Wu Long Peng Sheng' in 1971 in Heze, Shandong Province (Li, 1999, p. 112). In this study, detectable variations in the leaves of 'Wu Long Peng Sheng' were found, mainly including the three petiole length variables $\left(\mathrm{L}_{7}, \mathrm{~L}_{11}\right.$, and $\left.\mathrm{L}_{14}\right)$ and the full length of the first lateral compound leaf $\left(\mathrm{L}_{10}\right)$ with which $\mathrm{Z}_{2}$ (with a contribution of $28.86 \%$ ) was correlated highly, indicating that 'Wu Long Peng Sheng' itself possessed morphological variability.

Only a moderate correlation $(r=0.41)$ was detected between morphology and RAPD (random amplified polymorphic DNA) molecular markers in Rheum L. spp. (culinary rhubarb cultivars) (Persson et al., 2000). In Lolium perenne L. (perennial ryegrass), there was no significant relationship between morphological and either AFLP (amplified fragment length polymorphism) $(r=0.06)$ or STS (sequence tag sites) $(r=0.42)$ distances (Roldán-Ruiz et al., 2001). However, in Chaenomeles Lindl. (Rosaceae), a comparatively higher correlation $(0.71, p=0.049)$ was found between RAPDs and leaf shape descriptors ( Rumpunen and Bartish, 2002). In this study, disparity between morphological and ISSR data is not surprising, as morphological characters usually are regulated by multiple genes and ISSR markers are dominant. These two kinds of characters do not necessarily have direct association. Indeed, it should be remembered that the morphological characters may also be affected by environmental factors to some extent, although this possibility had been minimized by sampling and PCA screening strategies.

In conclusion, there exist large variations in leaf morphology of tree peony cultivars due to the influences from environmental conditions and developmental levels. However, twelve morphological characters of nos. 3, 4, and 5 biternately compound leaves from the base of a shoot at the middle crown of the plant are valuable characters for cultivar identification. An ISSR marker system could be used to conduct precise and rapid discrimination of tree peony cultivars without influences from environments. ISSR fingerprinting patterns were same among individual plants within a cultivar. This agreed with the fact that all individuals within a cultivar came from same parent plant through vegetative propagation. Also, our results suggest that genetic differentiations have occurred simultaneously and significantly at leaf morphological and ISSR molecular levels during the long-term artificial selections at the flower part of tree peony cultivars. Further studies on genetic variations of leaf morphology (also other vegetative characters) and ISSR markers through large-scale sampling of tree peony cultivars may be useful for improving the system of classification and identification.

\section{Literature Cited}

Chen, D.M. and Y.J. Ding. 1992. Appraisal system on main character for peony varieties. Acta Agr. Universitis Henanensis 26(2):187-193.

Chen, X.M., G.S. Zheng, and L. Meng. 2002. RAPDPCR analysis of genetic diversity of different colour 35 tree Paeonia cultivars. Scientai Ag. Sinica 35:546-551.

Chen, X.M., G.S. Zheng, and S.W. Zhang. 2001 RAPD analysis of tree peony cultivars. Acta Hort. Sinica 28(4):370-372.

Doyle, J.J. and J.L. Doyle. 1987. A rapid DNA isolation procedure for small quantities of fresh leaf tissue. Phytochem. Bul. 19:11-15.

Ge, S., M.X. Wang, and Y.W.Chen. 1988. An analysis of population genetic structure of mason pine by isozyme technique. Scientia Silvae Sinicae 24(4):399-409.

Godwin, I.D., E.A.B. Aitken, and L.W. Smith. 1997. Application of inter simple sequence repeat (ISSR) markers to plant genetics. Electrophoresis 18:1524-1528.

Hamada, M, T. Hosoki, and K. Inaba. 1989. Morphological peony cultivars classification based on multivariate analysis. J. Jpn. Soc. Hort. Sci. 58(3):697-704.

Harding,A. 1993. The peony. Sagapress, Inc.-Timber Press, Inc., Portland, Ore.

Haw, S.G. and L.A. Lauener. 1990. A review of the intraspecific taxa of Paeonia suffruticosa Andr. Edingb. J. Bot. 47(3):273-281.

Hong, D.Y. and K.Y. Pan. 1999. A revision of the Paeonia suffruticosa complex (Paeoniaceae). Nordic Journal of Botany 19: 289-299.

Hosoki, T., D. Kimura, R. Hasegawa, T. Nagasako, K. Nishimoto, K. Ohta, M. Sugiyama, and K. Haruki. 1997. Comparative study of tree peony (Paeonia suffruticosa Andr.) cultivars and hybrids by random amplified polymorphic DNA (RAPD) analysis. J. Jpn. Soc. Hort. Sci. 66(2):393-400.

Kessenich, G.M. 1990. The American hybrid peony. Amer. Peony Soc., Hopkins, Minn.

Li, J.J. 1999. Chinese tree peony and herbaceous peony. China For. Publ. House, Beijing.

Li, M.X. and X.F. Zhang. 1982. A cytogenetic observation on triploid Paeonia suffruticosa. Hereditas (Beijing) 4(5):19-21.
Pei, Y.L., Y. Zou, Z. Yin, X.Q. Wang, Z.X. Zhang, and D.Y. Hong. 1995. Preliminary report of RAPD analysis in Paeonia suffruticosa Subsp. spontanea and Paeonia rockii. Acta Phytotaxonomica Sinica 33(4):350-356.

Persson, H.A., K. Rumpunen, and L.K. Mollerstedt. 2000. Identification of culinary rhubarb (Rheum spp.) cultivars using morphological characterization and RAPD markers. J. Hort. Sci. Biotechnol. 75(6):684-689.

Rohlf, F.J. 1997. NTSYSpc: Numerical taxonomy and multivariate analysis system. version 2.02a. Appl. Biostatistics, New York.

Roldán-Ruiz, I., F.A.V. Eeuwijk, T.J. Gilliland, P. Dubreuil, C. Dillmann, J. Lallemand, M.D. Loose, and C.P. Baril. 2001. A comparative study of morphological methods of describing relationship between perennial ryegrass ( $\mathrm{LO}$ lium perenne L.) varieties. Theor. Appl. Genet. 103:1138-1150.

Rumpunen, K. and I.V.Bartish. 2002. Comparison of differentiation estimates based on morphometric and molecular data, exemplified by various leaf shape descriptors and RAPDs in the genus Chaenomeles (Rosaceae). Taxon 51:69-82.

Sang, T., D.J. Crawford, and T.F. Stuessy. 1997. Chloroplast DNA phylogeny, reticulate evolution, and biogeography of Paeonia (Paeoniaceae) American Journal of Botany 84:1120-1136

Stern, F.C. 1946. A Study of the Genus Paeonia. Royal Hort. Soc., London.

Swofford, D.L. 2001.PAUP*: Phylogenetic analysis using parsimony (*and other methods). version 4.0b10. Sinauer, Sunderland, Mass.

Wang, L.Y. 1998. Chinese tree peony (English ed.). China For. Publ. House, Beijing.

Wang, X.D., Z.P. Wang, and Y.P. Zou. 1996. An improved procedure for nuclear DNA isolation from silica-gel dried leaves of wild grapevine. Plant Mol. Biol. Rpt. 14(4):369-373.

Yu, H. 1998. The tree peony. Shanghai Science \& Technology Press, Shanghai.

Yu, H. and N.C. Yang. 1962. Evolution and formation of Chinese tree peony cultivars. Acta Hort. Sinica 1-2:175-186.

Yuan, T., and L.Y. Wang. 2003. Morphological studies on Paeonia sect. Moutan subsect. Vaginatae in China. Acta Hort. Sinica 30:187-191.

Zhou, J.Q. 1962. An approach on flower form classification of tree peony and peony cultivars. Acta Hort. Sinica 1-3-4:351-360.

Zhou, ZQ., K. Y. Pan, and D.Y. Hong. 2003. Phylogenetic analyses of Paeonia section Moutan (tree peonies, Paeoniaceae) based on morphological data. Acta Phytotaxonomica Sinica 42(5):436-446.

Zou, Y.P., M.L. Cai, and Z.P. Wang. 1999. Systematic studies on Paeonia sect. Moutan DC. based on RAPD analysis. Acta Phytotaxonomica Sinica 37:220-227. 